\title{
ONE DIMENSIONAL MOTION WITH ICT BASED LEARNING: IMPROVING THE PHYSICS TEACHER CANDIDATES' SCIENCE PROCESS SKILLS AND ATTITUDES
}

\author{
Ade Yeti Nuryantini*1, Ea Cahya Septia Mahen ${ }^{2}$ \\ ${ }^{1,2}$ Department of Physics Education, Universitas Islam Negeri Sunan Gunung Djati Bandung, Indonesia \\ ${ }^{*}$ Correspondence address: ade.yeti@uinsgd.ac.id
}

Received: July $24^{\text {th }}, 2018$. Accepted: October $21^{\text {st }}, 2018$. Published: October $28^{\text {th }}, 2018$

\begin{abstract}
Education nowadays is demanded to produce students who have beneficial skills of the 21st century in dealing with problems in the era of information and digital technology. Therefore, it is necessary to change the emphasis of learning patterns. In this paper, the results of the application of 21 st-century skills in learning Basic Physics 1 in the Physics Education Study Program, UIN Sunan Gunung Djati Bandung using a scientific approach is presented. Learning activities were conducted based on low budget materials and ICT in the form of tracker software. The results showed that students were skilled in using tracker (90\%), had science processing skills (excellent $5.2 \%$, good $74.0 \%$, and fair $20.8 \%$ ), and fostered curiosity (92.0\%), careful attitude (92.2\%), caring for the environment (73.0\%), honest (93.0\%), and cooperative (97.0\%).
\end{abstract}

() 2018 Physics Education, UIN Raden Intan Lampung. Indonesia

Keywords: ICT, tracker, 21st-century skills.

\section{INTRODUCTION}

One-dimensional motion is one of the materials taught in class for first-grade senior high school. In the revised 2013 curriculum, the basic competencies for one-dimensional motion material are analyzing physical quantities in straight motion with constant velocity and straight motion with constant acceleration (still) including its physical meaning and presents experimental results data and graphs to investigate the motion properties of objects that move straight at a constant velocity and move straight with constant acceleration (fixed) and their physical meaning. One-dimensional motion material is an important material and becomes the basis for further mechanics discussion (Rosenblatt \& Heckler, 2011; Suyuti, Kusairi, \& Sutopo, 2016).

One-dimensional motion is the motion of an object on a straight track. Onedimensional motion material is limited to the motion of objects in the horizontal ( $\mathrm{x}$ axis) and vertical (y-axis) paths. Straight motion on the $\mathrm{x}$-axis is known as uniform rectilinear motion (GLB). While straight on the y-axis, it is known as an accelerated uniform rectilinear motion (GLBB).

GLB and GLBB have their own characteristics. In the high school level, students must be able to analyze the characteristics of physical quantities. To help students finding their own concepts of GLB and GLBB, teachers must be creative in developing materials, managing the learning process, and using learning methods and models.

One of the efforts that can be taken by the teacher in learning the GLB and GLBB material is the use of ICT (Information, Communication, Technology) in the form of computer use (Arafiana \& Setyarsih, 2014; Bonato \& Gratton, 2017; Milner Bolotin \& Antimirova, 2009; Wijayanto \& Susilawati, 2015). In this article, the researchers focused on video analysis with the use of computers using tracker software in the learning process to analyze the characteristics of physical quantities on GLB and GLBB. Simulations using computers are closely related to forms of constructivism learning, namely learning 
scientific discoveries (Jong \& Joolingen, 1998).

Tracker is an application used to analyze video and modeling (Belloni et al., 2013; Brown \& Cox, 2009; Wee, Chew, Goh, Tan, \& Lee, 2012; Wee \& Leong, 2015). Tracker is an open source application that can be accessed for free on the open source physics website. Tracker is made to be applied for physics learning purposes. To run the tracker application, other supporting applications are needed, namely Java 1.6 or higher, quick time, video converter, a video for windows (Wee et al., 2012). Tracker has the ability to manually and automatically track positions on time, speed, acceleration, mass center, and other kinematic quantities (Brown \& Cox, 2009; Mariati, Betty, \& Sehat, 2017; Tirtasari, Latief, Amahoru, \& Azizah, 2015).

The use of tracker in physics learning is seen as an effective way in improving students' science process skills (Habibbuloh \& Madlazim, 2014; Zulika, Wijaya, Masitoh, Utari, \& Titin, 2018). The tracker can encourage students to feel like a scientist (Wee \& Leong, 2015). But unfortunately, the tracker is not widely used by teachers at school. The researchers interviewed 20 physics teachers on August 8,2017 , regarding the use of tracker. The result of the interview revealed that the physics teachers did not know what tracker is and what benefits it could provide. Therefore in this research, tracker software was used in basic physics subject to encourage the students in using the tracker since they are expected to be a professional physics teacher after completing their study.

The objective of this study is to obtain a deeper insight of the students of physics education in utilizing the tracker software to improve science process skills, mastery of concepts, and as well as their perception and attitudes like their curiosity, carefulness, environmental awareness, honesty, and cooperativity.

\section{METHOD}

The study was conducted in the basic physics course 1 , the first semester of the 2016/2017 academic year. The population in this study were 2 classes of Physics Education Study Program. The sampling technique used was saturated sampling technique. The entire population which consisted of 77 students were used as research samples. The research instrument used was the science process skills assessment rubric, questionnaire, and mastery test concept. The science process skills assessment rubric covers nine aspects, namely: (1) asking questions, (2) making hypotheses, (3) planning experimental trials / procedures, (4) using tools and materials, (5) carrying out experiments: collecting and recapping data, (6) interpreting and analyzing data, (7) classifying, (8) concluding, and (9) communicating. The assessment rubric uses four levels of achievement, namely 1 (poor), 2 (fair), 3 (good), 4 (excellent). A questionnaire was used to obtain data on students 'ability to use tracker software and to obtain data on students' perceptions and attitudes on the course. The attitude questionnaire of students was analyzed using the Guttman scale. Each student's answer to the statement is grouped on an agree (SS) category, and disagree (TS) category. The test was used to obtain data about the students' mastery progression of concepts on one-dimensional motion material.

The quantitative analysis of the students' science process skills was done by calculating the percentage of the number of students for each achievement with poor categories, fair, good, excellent based on the total number of scores for each aspect of the science process skills. To get the score, the score obtained is converted to a scale of 100 with the following equation (Nuryantini, Setiadi, Kurniawan, \& Farida, 2015). 


$$
\text { Score }=\frac{\text { Obtained score }}{\text { Maximum total score }}
$$

The obtained science process skills score then grouped based on categories; poor, fair, good, and excellent. The categories are based on the maximum score $(4 \times 9=36)$ and minimum score $(1 \times$ $9=9$ ). The criterion is presented in the following Table 1 .

Table 1. Scientific report assessment criteria

\begin{tabular}{lcc}
\hline \multicolumn{1}{c}{ Criteria } & Total Score & Score \\
\hline Maximum & $9 \times 4=36$ & 100 \\
Minimum & $9 \times 1=10$ & 25 \\
Excellent & $29-36$ & 81,25 to 100,0 \\
Good & $23-29$ & 62,51 to 81,25 \\
Fair & $16-22$ & 43,76 to. 62,50 \\
Poor & $9-15$ & 25 to 43,75 \\
\hline
\end{tabular}

The criteria in Table 1 were determined by dividing each score range by a quarter of the overall score. A quarter of the low score in the score range of 9 to 15 has a maximum score of 43.75 (see table 1). Thus, the categorization of the science process skills is corresponding to the scale set for the achievement category in the range of 1 to 4 .

Students' ability in using tracker software, perceptions and attitudes toward the course are presented in a percentage form. The percentage is calculated using the following equation.

$$
\mathrm{T}=\left(\sum \mathrm{J}\right) / \mathrm{N} \times 100 \%
$$

Information:

$\mathrm{T}=$ Percentage of each statement.

$\mathrm{J}=$ total answer of each group.

$\mathrm{N}=$ number of students

\section{RESULTS AND DISCUSSION \\ Results}

The Students' Ability to Use Tracker

Teaching and learning approach used in the course was the scientific approach. In scientific approach, learning strategies are suggested using disclosure / researchbased learning (discovery / inquiry learning), based on problem solving (work based solving) and work-based (projectbased learning) (Duch, Groh, \& Allen, 2001; Khairiyah, 2017; Kuhlthau, Maniotes, \& Capsari, 2007; Wieman \& Gilbert, 2015).

Learning activities on one-dimensional motion material are carried out using discovery strategies. Discovery learning requires students to be able to design their knowledge acquisition independently. Courses are carried out through inexpensive material-based experiments using media balls dropped from a certain height and rolled on a flat table. The ball motion is then analyzed using tracker software. The learning steps taken are shown in Table 2.

The use of tracker software is intended to make students as candidates for skilled physics teachers to use media, technology, information and communication (ICT). The ability of pre-service teachers in using ICT will be transferred to students later in school. As in the syllabus of senior high school (SMA) or Madrasah Aliyah (MA) physics subjects which state that science learning is expected to deliver students to fulfill 21st-century abilities, including mastery of ICT (Trilling \& Fadel, 2009; Wan Husin et al., 2016). Table 3 below illustrates the ability of students teacher to use tracker software in the basic physics 1 course. 
Table 2. Learning steps using discovery strategy

\begin{tabular}{|c|c|c|}
\hline Learning Steps & Students Learning Activities & Competences Being Developed \\
\hline Stimulation & $\begin{array}{l}\text { Students observed the demonstration of a ball } \\
\text { being dropped from a certain height and } \\
\text { rolled on a flat table. }\end{array}$ & $\begin{array}{l}\text { Developing sincerity and thorough } \\
\text { character, and the ability to observe and seek } \\
\text { information. }\end{array}$ \\
\hline Problem & Students ask a question regarding the & Growing curiosity, creativity, and ability in \\
\hline Identification & $\begin{array}{l}\text { movement of the ball which fell and rolled on } \\
\text { the flat table. }\end{array}$ & $\begin{array}{l}\text { searching for information and developing } \\
\text { the question. }\end{array}$ \\
\hline Data collection & $\begin{array}{l}\text { Students conducted an experiment on } \\
\text { dropping a ball form a certain height and } \\
\text { rolled it on a flat table and recorded the } \\
\text { occurrence in a video. }\end{array}$ & $\begin{array}{l}\text { Accuracy, honesty, social interaction } \\
\text { between friends in groups, responsibility, } \\
\text { communication. }\end{array}$ \\
\hline $\begin{array}{l}\text { Data processing and } \\
\text { verification }\end{array}$ & $\begin{array}{l}\text { Students analyzed the video of objects' } \\
\text { motion using tracker software, so that } \\
\text { obtained the position graph against time (s-t), } \\
\text { velocity versus time graph }(\mathrm{v}-\mathrm{t}) \text {, and the graph } \\
\text { of acceleration with time (a-t). } \\
\text { Students distinguished position graphs to time } \\
\text { (s-t), velocity to time graphs ( } \mathrm{v}-\mathrm{t}) \text {, and graphs } \\
\text { of acceleration to time (a-t) of the motion of } \\
\text { the ball dropped and the motion of the rolling } \\
\text { ball and confirmed it by one-dimensional } \\
\text { motion theory. }\end{array}$ & $\begin{array}{l}\text { Developing honesty, thoroughness, } \\
\text { discipline, obeying the rules, working hard, } \\
\text { having the ability to use effective reasons, } \\
\text { implementing procedures and the ability to } \\
\text { think inductively and deductively in } \\
\text { concluding, being able to apply technology } \\
\text { effectively. }\end{array}$ \\
\hline Conclusion & $\begin{array}{l}\text { Students described the difference in the } \\
\text { motion of the dropped ball (the irregularly } \\
\text { changing straight motion), and the ball rolled } \\
\text { on a flat table (regular straight motion). }\end{array}$ & $\begin{array}{l}\text { Developing honest, thorough, tolerant } \\
\text { attitudes, the ability to think systematically, } \\
\text { expressing opinions in brief and clear, and } \\
\text { developing good and correct language } \\
\text { skills. }\end{array}$ \\
\hline
\end{tabular}

Table 3. Students' ability in using software tracker.

\begin{tabular}{llc}
\hline No & \multicolumn{1}{c}{ Notes } & $\begin{array}{c}\text { Percentage } \\
(\mathbf{\%})\end{array}$ \\
\hline 1 & Installing software tracker. & 94,8 \\
2 & Importing video. & 100 \\
3 & Cutting video. & 94,8 \\
4 & Calibrating. & 76,7 \\
5 & Deciding coordinate point. & 92,2 \\
7 & Signing the motion of objects. & 87,1 \\
9 & Importing graphic and table in & 84,5 \\
& other applications & \\
\hline & Average & 90,0
\end{tabular}

The data written in Table 3 show that generally, students have already been mastering the operation of tracker software even though $74 \%$ of students have never used it.

\section{Science Process Skills}

The skills of students in operating the tracker software are supported by the familiarity of computers for students and the ease of operating tracker software. Students' ability to operate tracker software can build students' science process skills in finding the concept of one-dimensional motion. Table 4 illustrates the percentage of the number of students based on the science process skills category.

Table 4. The Percentage of Science Process Skills.

\begin{tabular}{ccc}
\hline $\begin{array}{c}\text { Category of } \\
\text { science process } \\
\text { skills }\end{array}$ & $\begin{array}{c}\text { Number of } \\
\text { students }\end{array}$ & $\begin{array}{c}\text { Percentage } \\
(\%)\end{array}$ \\
\hline Excellent & 4 & 5.19 \\
Good & 57 & 74.03 \\
Fair & 16 & 20.78 \\
Poor & 0 & 0 \\
\hline
\end{tabular}

Students' science process skills are generally categorized as good as it is indicated by an average score of 70 . Based on the science process skills category, $4 \%$ of students are classified under excellent categories, $74 \%$ are classified under good, and no students have poor categories. Students' science process skills which 
were built through motion analysis activities using tracker software consists of nine aspects

The following is a detailed explanation of each aspect of the students' science process skills.

Asking questions. Students ability in asking and conducting question is $60 \%$ of students are classified under excellent category, and $39 \%$ are in a good category, $1 \%$ are in the fair category, as shown in Figure 1a. The ability of students to ask questions represents that students have been able to show the relationship of two variables, the question relates with the results of the observations, and the questions asked are related to all observed phenomena. The following are examples of several questions asked by students: 1 . Is there a difference between motion in the direction of vertical and horizontal direction?; 2. What is the effect of mass (m) on speed (v) on the $\mathrm{x}$-axis?; 3. What is the effect of mass (m) on speed (v) on the $y$-axis?; 4. What is the difference between mass graph $(\mathrm{m})$ and speed $(\mathrm{v})$ on the $\mathrm{x}$-axis and y-axis?

Making the hypothesis. The hypothesis is an important part of science process skills. Figure $1 \mathrm{~b}$ shows the ability of students in formulating hypotheses. $11 \%$ of students submitted hypotheses very well, $49 \%$ were good, and $40 \%$ were fine. There is no one student in the category of Poor. The hypothesis proposed by students has shown a complete idea, based on prior knowledge and or observation, and also specifically related to the problem or question. Although students do not follow it up with further reason about the thoughts behind the prediction or hypothesis and their considerations. The following are some hypotheses made by students: 1 . The higher the initial position of the object being dropped the faster the speed of the object; 2 . The volume of an object will not affect the motion of objects in the onedimensional medium in the vertical position (on the y-axis); 3 . The mass of an object greatly affects the speed of an object. If an object is dropped on a vertical medium, the heavier the mass of an object the faster the speed of an object will increase; 4. There is a significant difference between motion in the direction of the $\mathrm{x}$ and $\mathrm{y}$-axes.

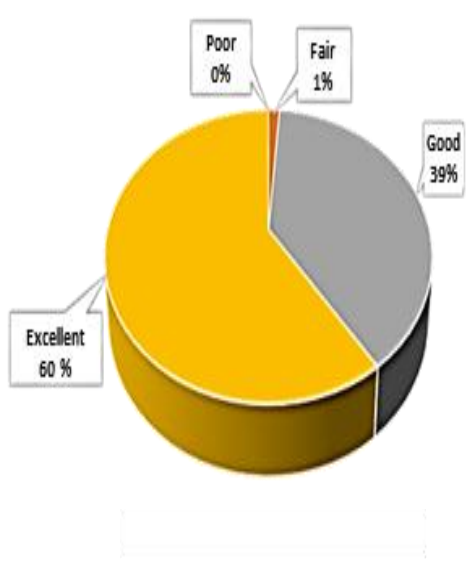

(a)
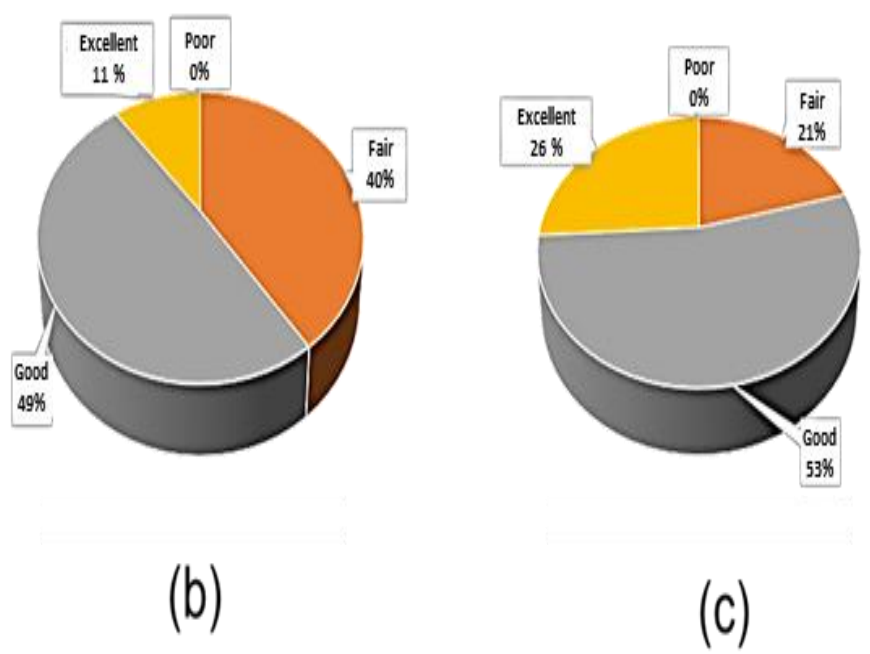

Figure 1. Students' science process skills (a) asking questions, (b) formulating hypotheses, (c) planning experiments 


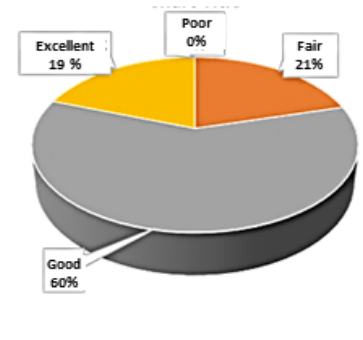

(d)

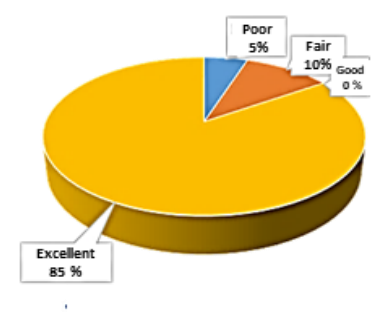

(g)

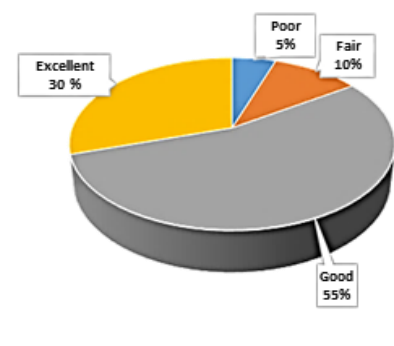

(e)

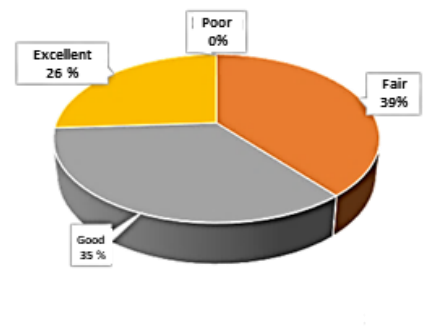

(h)

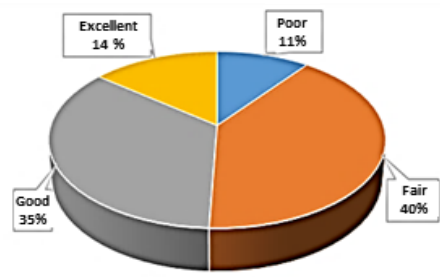

(f)

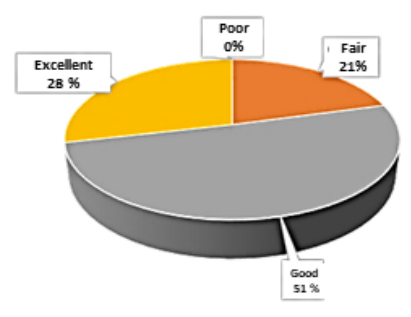

(i)

Figure 1. (d) using tools and materials, (e) collecting and recapping data, (f) analyzing data, (g) classifying, (h) making conclusions, and (i) communicating.

Planning experiments. In the experimental planning process, students describe the experimental procedures performed. The skills of students in planning experiments are shown in Figure 1c. $19 \%$ of students have the skills to plan experiments with excellent categories, $40 \%$ good category, and $21 \%$ with the fair category. In preparing the experimental procedure, students can sort the procedures to be carried out, the sequence of all procedures is arranged logically, and able to identify experimental variables and control variables.

Using tools and materials. After the trial procedure is made, the next task is the use of the correct tools and materials. Generally, students can use the tools and materials well as shown in Figure 1d. Students have been able to choose and use the tools/instruments needed.

Collecting and recapping data. Data collected by students is a video of motion of objects in the vertical and horizontal direction. Videos are recorded using the recording facilities on the phone. The ability of students to record the motion of objects and recap the data can be seen in
Figure 1e. $30 \%$ of students have the ability to collect and recap the data with excellent categories, $55 \%$ in good categories, $10 \%$ in fair categories and $5 \%$ in poor categories. The data collected by most students have been recapitulated in the right format in the form of charts and graphs, the measurements are determined precisely, the data collected has uniform units, the sequence is logical, and the information presented easy to read and interpret.

Analyzing Data. Data analysis is an activity that is carried out after the data had been collected. The students' skills in analyzing the data are $14 \%$ of students are categorized as excellent, $35 \%$ is good, $40 \%$ is fair, and $11 \%$ are poor as shown in Figure 1f. Data analysis is seen as a difficult activity by students. Students have difficulty in interpreting data with the concepts they will build. The biggest obstacle is because the understanding of student toward the concepts on straight motion material is very low. In data analysis activities, students must check the data to see whether the recapitulated information is logical, the sentences that are expressed to explain complete data 
describe complete ideas, can verbally explain how data is organized, can accurately write experimental results based on data, can determine whether data has been collected/captured accurately, evaluating the relevance of data collected with the original question.

Grouping. The ability of students to classify is very good as shown by $85 \%$ of students in the excellent category shown in Figure 1g. In this grouping aspect students have been able to distinguish data and share it in groups so that data can be observed and clearly distinguished.

Concluding. In making conclusions, $26 \%$ of students are classified as very good, $35 \%$ is good and $39 \%$ are fair as illustrated in Figure 1h. The conclusions made by the students showed that the sentences and ideas used were complete, determining the results of the experiment. However, $39 \%$ of students had not been able to make conclusions that clearly describe the original questions, and interpret the intent of the data analyst results by applying them correctly to a bigger scientific concept.
Communicating. In submitting research reports in oral or written form, students must be able to communicate it well. In the research conducted, the communication skills reviewed were written forms. Overall students have been good at writing communication in the form of reports, which is shown by $28 \%$ of students in excellent categories and $51 \%$ of good categories as shown in figure 1 (i). Communication skills are characterized by experimental reports made by students using active sentences, easy to understand, using standard language, and using enhanced spelling.

\section{Mastery of Concepts}

Students' science process skills in finding a concept are important things that need to be explored. Students high-level thinking skills and their concepts mastery can be developed through science process skills. Figure 2 is a graph of increasing the mastery of students' concepts on onedimensional motion material obtained from the results of the pretest and posttest.

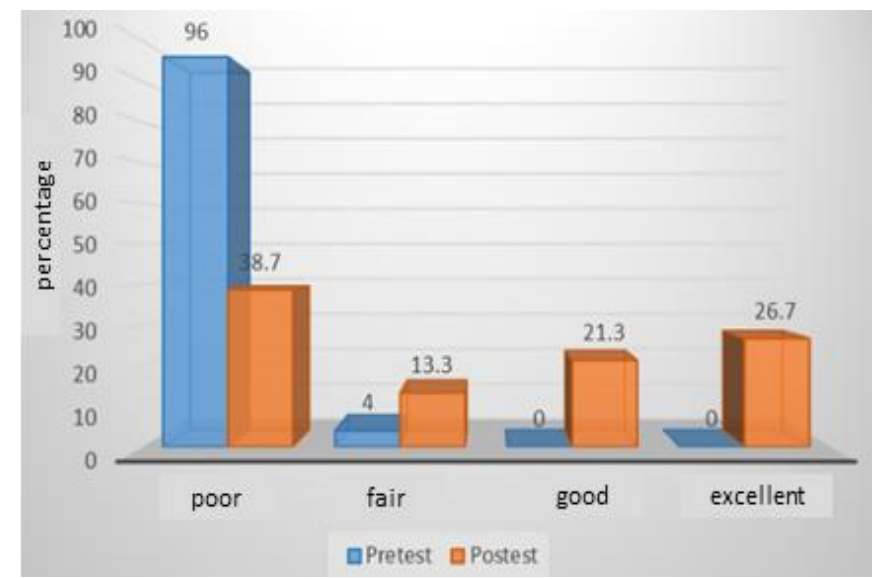

Figure 2. Graph of Students' Growth on Concepts Mastery in One-Dimensional Motion Material

\section{Students' Perception and Attitudes}

The results of observations of student activities in basic physics course indicate that all students actively play a role in video data retrieval and data analysis. Students were enthusiastic and happy. To strengthen students' perception data in basic physics lectures, 10 items were distributed to the questionnaire which described three aspects, namely feeling of pleasure, activity, and mastery of the concept. The data obtained from the questionnaire are illustrated in Table 5 below 
Data obtained from questionnaires about student perceptions related the course taken to support the results of observations. Data from the questionnaire showed that $95.2 \%$ of students felt happy, $92.9 \%$ of students were active in the learning activity and $87.3 \%$ of students were helped in improving the mastery of one-dimensional motion concept. Students are usually afraid of facing basic physics lectures, passive because they only listen and record, it is difficult to understand the concept of physics because concepts are studied abstractly. But with the motion analysis activity, students can immediately observe the GLB and GLBB phenomena and find their own characteristics of GLB and GLBB. Together with other friends, they enthusiastically take every step and activity of the course. The course gave also encourages curiosity, thorough, honesty and excellent cooperation. Moreover, students' awareness of motion phenomenon in their environment can be classified as good, as shown in the graph in Figure 3.

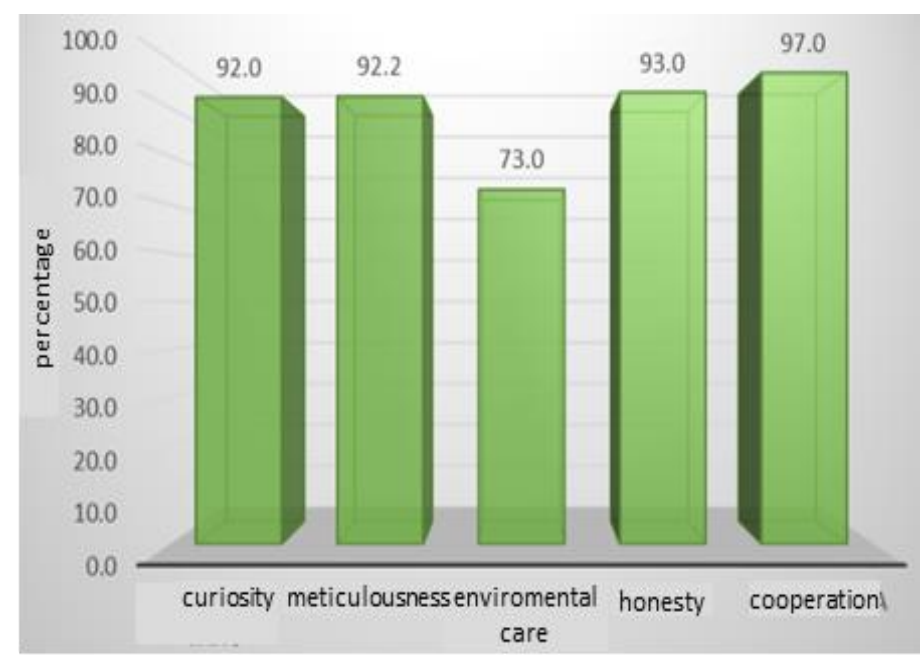

Figure 3. Percentage of curiosity, meticulousness, environmental care, honesty, and cooperation.

Course with an ICT-based discovery strategy has many positive effects on student learning outcomes both direct teaching and indirect teaching (Dwianto, Wilujeng, Prasetyo, \& Suryadarma, 2017; Sabon \& Sumadi, 2016). Mastery of concepts and skills is the result of direct learning, while attitudes that grow from courses are indirect learning outcomes (Usmeldi, 2016). Courses should be interactive, inspiring, fun, challenging, motivating students to participate, as well as providing sufficient space for the initiative, creativity, and independence.

Table 5. Students' Perception of the Study

\begin{tabular}{clc}
\hline No & Aspect notes & Number of students (\%) \\
\hline 1 & $\begin{array}{l}\text { Glad to follow the study by analyzing the motion of the ball using } \\
\text { tracker software. }\end{array}$ & 95,2 \\
2 & $\begin{array}{l}\text { Actively follow the learning process by analyzing ball motion using } \\
\text { tracker software. }\end{array}$ & 92,9 \\
3 & $\begin{array}{l}\text { Analyzing ball motion using tracker software to increases mastery of } \\
\text { concepts. }\end{array}$ & 87,3 \\
\hline
\end{tabular}


Table 6. Students' abilities that can be developed from $21^{\text {st-century skills }}$

\begin{tabular}{|c|c|c|}
\hline \multicolumn{2}{|l|}{ 21th-century skills } & Description \\
\hline $\begin{array}{l}\text { Learning and innovation } \\
\text { skills }\end{array}$ & $\begin{array}{l}\text { Critical thinking and } \\
\text { problem-solving skills }\end{array}$ & $\begin{array}{l}\text { Students are able to use effective reasons, } \\
\text { use systems thinking, make judgments and } \\
\text { decisions, and solve problems. }\end{array}$ \\
\hline & $\begin{array}{l}\text { Communication and } \\
\text { collaborative skills }\end{array}$ & $\begin{array}{l}\text { Students are able to communicate clearly } \\
\text { and collaborate with others. }\end{array}$ \\
\hline & $\begin{array}{l}\text { Creative and } \\
\text { innovation skills }\end{array}$ & $\begin{array}{l}\text { Students are able to think creatively, work } \\
\text { creatively with others, and apply } \\
\text { innovation. }\end{array}$ \\
\hline \multirow[t]{3}{*}{ Digital literacy skill } & Information literacy & $\begin{array}{l}\text { Students are able to access and assess } \\
\text { information, use and manage information. }\end{array}$ \\
\hline & Media literacy & $\begin{array}{l}\text { Students are able to analyze the media and } \\
\text { create media products. }\end{array}$ \\
\hline & ICT Literacy & $\begin{array}{l}\text { Students are able to apply technology } \\
\text { effectively. }\end{array}$ \\
\hline \multirow[t]{5}{*}{ Life and career skills } & $\begin{array}{l}\text { Flexibility and } \\
\text { adaptability: }\end{array}$ & $\begin{array}{l}\text { Students are able to adopt changes and are } \\
\text { flexible in providing feedback and facing } \\
\text { criticism. }\end{array}$ \\
\hline & $\begin{array}{l}\text { Initiative and self- } \\
\text { regulating }\end{array}$ & $\begin{array}{l}\text { Students are able to manage goals and time, } \\
\text { work independently, become students who } \\
\text { are able to self-regulate. }\end{array}$ \\
\hline & $\begin{array}{l}\text { Social and intercultural } \\
\text { interaction }\end{array}$ & $\begin{array}{l}\text { Students are able to interact socially with } \\
\text { others, work effectively in different groups. }\end{array}$ \\
\hline & $\begin{array}{l}\text { Productivity and } \\
\text { accountability. }\end{array}$ & $\begin{array}{l}\text { Students are able to manage projects and } \\
\text { produce products. }\end{array}$ \\
\hline & $\begin{array}{l}\text { Leadership and } \\
\text { responsibility. }\end{array}$ & $\begin{array}{l}\text { Students are able to guide and lead others; } \\
\text { are responsible for others. }\end{array}$ \\
\hline
\end{tabular}

(Trilling \& Fadel, 2009)

\section{Discussion}

The learning outcomes present above have an agreement with 21 st-century skills. 21stcentury skills require students to develop their abilities, as described in Table 6. 21st-century skills can be used for decision making in dealing with problems in the era of information and digital technology.

In order to actualize the 21 st-century skills in the world of education in Indonesia, the Ministry of Education and Culture of the Republic of Indonesia has adapted it along with the adaptation of scientific approach and authentic assessment in developing a new curriculum, the 2013 curriculum. All three concepts were adapted to develop education towards creative Indonesia in 2045 (Murti, 2014).
The learning process touches three domains, namely knowledge (know what), skills (know how) and attitude (know why). The end result of the learning process is to improve and balance soft skills and hard skills in the form of knowledge and skills. In the 21st century learning, the three domains above are known as KSAVE namely knowledge, skills, attitudes, values and ethics (Binkley, Erstad, \& Herman, 2012; Salonen, Hartikainen-Ahia, Hense, Scheersoi, \& Keinonen, 2017). Knowledge is the same as skills, and attitudes, values and ethics as well as attitudes. The results of the study conducted in this study include three domains, namely knowledge, skills in the form of science process skills with aspects of (1) asking questions, (2) making hypotheses, (3) planning trial / trial procedures, (4) using tools and materials, (5) carrying out experiments: 
collecting and recapping data, (6) interpreting and analyzing data, (7) classifying, (8) concluding, (9) communicating, and skill in using tracker software as part of ICT literacy and curiosity, careful, caring for the environment, honest and cooperation.

\section{CONCLUSION AND SUGGESTION}

21st-century skills can be trained through basic physics lectures by using discovery strategies. Low budget materials around and ICT can be used to present physics phenomena to students. Phenomena are presented to build concepts, laws, or learned principles. Learning outcomes conducted in this study include three domains, namely knowledge, skills in the form of science process skills with aspects of (1) asking questions, (2) making hypotheses, (3) planning experimental trials / procedures, (4) using tools and materials, ( 5) carrying out experiments: collecting and recapping data, (6) interpreting and analyzing data, (7) classifying, (8) concluding, (9) communicating, and skill in using tracker software as part of ICT literacy and curiosity, careful, caring for the environment, honest and cooperation. Students' perceptions of the course indicate happiness, activeness, and encouragement in understanding the materials.

\section{REFERENCES}

Arafiana, R. N., \& Setyarsih, W. (2014). Penerapan pembelajaran gerak lurus dengna media pembelajaran macromedia flash dalam menyajikan grafik untuk meningkatkan hasil belajar fisika siswa di SMPN 3 Nganjuk. Jurnal Inovasi Pendidikan Fisika, 3(2), 70-73.

Belloni, M., Christian, W., Brown, D., Belloni, M., Christian, W., \& College, D. (2013). Teaching Astronomy Using Tracker. The Physics Teacher, 51, 1149-151. https://doi.org/10.1119/1.4792008

Binkley, M., Erstad, O., \& Herman, J.
(2012). Defining Twenty-First Century Skills. In Assessment and Teaching of 21st Century Skills. Netherlands: Springer Netherlands. 17-66.

Bonato, J., \& Gratton, L. M. (2017). Using high-speed smartphone cameras and video analysis techniques to teach mechanical wave physics. Physics Education, 52(4), 1-5.

Brown, D., \& Cox, A. J. (2009). Innovative Uses of Video Analysis. The Physics Teacher, 47. https://doi.org/10.1119/1.3081296

Duch, B. J., Groh, S. E., \& Allen, D. E. (2001). The Power of Problem Based Learning. Virginia: Stylus Publishing.

Dwianto, A., Wilujeng, I., Prasetyo, Z. K., \& Suryadarma, I. G. P. (2017). The Development of Science Domain Based Learning Media Which is Integrated with Local Potential to Improve Science Process Skill and Scientific Attitude. Jurnal Pendidikan IPA Indonesia, 6(1), 23-31. https://doi.org/10.15294/jpii.v6i1.72 05.

Habibbuloh, M., \& Madlazim. (2014). Penerapan Metode Analisis Video Software Tracker Dalam Pembelajaran Fisika Konsep Gerak Jatuh Bebas Untuk Meningkatkan Keterampilan Proses Siswa Kelas X Sman 1 Sooko Mojokerto. Jurnal Pendidikan Fisika Dan Aplikasinya (JPFA), 4(1), 15-22.

Jong, T. De, \& Joolingen, W. Van. (1998). Scientific discovery learning with computer simulations of conceptual domains. Review of Educational Research, 68, 179-202.

Khairiyah, U. (2017). Melatihkan life skills melalui pembelajaran IPA dengan pendekatan scientific untuk meningkatkan hasil belajar siswa. AtThulab, 1(1), 33-41.

Kuhlthau, C. C., Maniotes, L. K., \& Capsari, A. K. (2007). Guided Inquiry 
Learning in The 21 Century. Uniteted States of America: Libraries Unlimited Inc.

Mariati, P. S., Betty, M. T., \& Sehat, S. (2017). The Problem Solving Learning Model by Using Video Recording on Experiments of Kinematics And Dynamics to Improve The Students Cognition and Metacognition. Jurnal Pendidikan Fisika Indonesia 13, 13(1), 25-32. https://doi.org/10.15294/jpfi.v13i1.1 0154.

Milner Bolotin, M., \& Antimirova, T. (2009). A brief introduction to video analysis. Physics in Canada, 65(2), 74.

Murti, K. E. (2014). Pendidikan Abad 21 dan Implementasinya pada Pembelajaran di Sekolah Menengah Kejuruan (SMK) untuk Paket Keahlian Desain Interior. Retrieved December 2, 2016, from http://p4tksb-

jogja.com/arsip/index.php?option=co m_content\&view=article\&id=478:pe ndidikan-abad-21-danimplementasinya-padapembelajaran-di-smk-untuk-paketkeahlian-desaininterior\&catid=68:pendidikan\&Itemi $\mathrm{d}=192$.

Nuryantini, A. Y., Setiadi, T., Kurniawan, \& Farida, I. (2015). The application of authentic assessment with feedback to improve the competence of mts students in constructing a scientific report of motion material in science learning. Jurnal Pendidikan Fisika Indonesia, 11(2), 108-116. https://doi.org/10.15294/jpfi.

Rosenblatt, R., \& Heckler, A. F. (2011). A systematic study of student understanding of the relationships between the directions of force, velocity, and acceleration in one dimension. Physical Review Special Topics-Physics Education Research, $7(2)$,

$1-20$.
https://doi.org/10.1103/PhysRevSTP ER.7.020112.

Sabon, E. A. S., \& Sumadi. (2016). Pengaruh model pembelajaran discovery learning terhadap prestasi belajar fisika pokok bahasan gelombang dan bunyi. Jurnal Universitas Sarjanawiyata Tamansiswa, 3(2), 74-83.

Salonen, A., Hartikainen-Ahia, A., Hense, J., Scheersoi, A., \& Keinonen, T. (2017). Secondary school students' perceptions of working life skills in science-related careers. International Journal of Science Education, 39(10), 1339-1352.

https://doi.org/10.1080/09500693.20 17.1330575 .

Suyuti, H., Kusairi, S., \& Sutopo. (2016). Pengembangan dan Penyetaraan Instrumen Tes Kinematika Gerak Lurus dengan Metode Linear. Jurnal Pendidikan Sains, 4(1), 17-24.

Tirtasari, Y., Latief, F. D. E., Amahoru, A. H., \& Azizah, N. (2015). Validasi Teknik Video Tracking Pada Praktikum Bandul Matematis Untuk Mengukur Percepatan Gravitasi Bumi. In Prosiding Seminar Kontribusi Fisika, 399-406.

Trilling, B., \& Fadel, C. (2009). 21st Century Skills: Learning for Life in Our Times. San Francisco: JosseyBass.

Usmeldi. (2016). the Development of Research-Based Physics Learning Model With Scientific Approach To Develop Students , Scientific Processing Skill. Jurnal Pendidikan IPA Indonesia, 5(1), 134-139. https://doi.org/10.15294/jpii.v5i1.58 02

Wan Husin, W. N. F., Mohamad Arsad, N., Othman, O., Halim, L., Rasul, M. S., Osman, K., \& Iksan, Z. (2016). Fostering students' 21 st-century skills through project-oriented problembased learning (POPBL) in an integrated STEM education program. 
Asia-Pacific Forum on Science Learning \& Teaching, 17(1), 60-77. Retrieved from https://www.ied.edu.hk/apfslt/v17_is sue1/\%0Ahttp://content.ebscohost.co $\mathrm{m} /$ ContentServer.asp? $\mathrm{T}=\mathrm{P} \& \mathrm{P}=\mathrm{AN} \&$ $\mathrm{K}=118111100 \& \mathrm{~S}=\mathrm{R} \& \mathrm{D}=\mathrm{ehh} \& \mathrm{Ebsc}$ oContent=dGJyMNLr40SeqLc4zOX 0OLCmr06ep65Sr664TLWWxWXS $\&$ ContentCustomer=dGJyMPGss0q1 qK5IuePfgeyx44Dt6fIA.

Wee, L. K., Chew, C., Goh, G. H., Tan, S., \& Lee, T. L. (2012). Using tracker as a pedagogical tool for understanding projectile motion. Physics Education, 47(4), 448-455. https://doi.org/10.1088/00319120/47/4/448.

Wee, L. K., \& Leong, T. K. (2015). Video Analysis and Modeling Performance Task to promote becoming like scientists in classrooms. American
Journal of Educational Research, $3(2)$, 197-207. https://doi.org/10.12691/education-32-13

Wieman, C., \& Gilbert, S. (2015). Taking a Scientific Approach to Science Education Part I-Research. Microbe, 10(4), 152-156.

Wijayanto, \& Susilawati. (2015). Rancangan Kinematika Gerak Menggunakan Alat Eksperimen Air Track Untuk Media Pembelajaran Fisika Berbasis Video. Jurnal Informatika Upgris, 1, 120-125.

Zulika, A. M., Wijaya, M. H., Masitoh, U., Utari, S., \& Titin. (2018). Profil keterampilan proses sains (KPS) siswa dalam menggunakan ragam media pembelajaran gerak melingkar di SMA. Jurnal Wahana Pendidikan Fisika, 3(1), 80-84. 